\title{
Second-Sphere Coordination Revisited
}

\author{
Zhichang Liu, Severin T. Schneebeli, and J. Fraser Stoddart*
}

\begin{abstract}
Since the concept of second-sphere coordination of transition metal complexes was introduced by Alfred Werner in 1913, the investigation of the phenomenon has emerged as a major thrust area - a significant part of which is based on the use of transition metal complexes as first coordination spheres as well as macrocycles as second-sphere ligands in promoting the assembly and dictating the main structural features of the secondsphere adducts. In this review, we first of all summarize the work carried out in our laboratory on the secondsphere coordination chemistry of transition metal complexes in the past three decades. Significant advances of relevance to the second-sphere coordination chemistry of square-planar gold complex anions with cyclodextrins are presented as the second part of this review.
\end{abstract}

Keywords: Crystallization · Cyclodextrins · Gold extraction · Molecular recognition · Square-planar gold anions

\section{Introduction}

Dating back 100 years, Alfred Werner, a Swiss chemist at the University of Zurich, won the first Nobel Prize in inorganic chemistry[1] for his achievements in elucidating the fundamental concepts of coordination in transition metal complexes (TMCs). Alfred Werner's most significant contribution to this field was to invent a unifying structural theory for coordination compounds - based on his concepts ${ }^{[2]}$ of primary and secondary valence, i.e. 'Haupt- und Nebenvalenz'. Primary valence describes the number of chemical bonds, which can be formed between a chemical element and ionizable ligands and is therefore equivalent ${ }^{[3]}$ to the oxidation state of an element in more current terminology. Secondary valence on the other hand, which is related to an element's coordination number, describes the maximum number of non-ionizable ligands associated with the TMC. Alfred Werner investigated correlations ${ }^{[2]}$ between the strengths of interactions involving primary and secondary valences in great detail, laying the foundations for an in-depth understanding of covalent and noncovalent bonding interactions. By creating a unifying structural theory for co-

\footnotetext{
${ }^{*}$ Correspondence: Prof. J. F. Stoddart

Department of Chemistry

Northwestern University

2145 Sheridan Road

Evanston, IL 60208

United States

Tel.: +1 847-491-3793

E-mail: stoddart@northwestern.edu
}

ordination compounds, Alfred Werner also brought the concept of second-sphere coordination into being. ${ }^{[4]} \mathrm{He}$ observed that ligands in the first coordination sphere of a TMC can interact with neutral or charged species to give a second-sphere adduct. Nowadays, second-sphere coordination is well-understood in terms of noncovalent bonding of chemical entities constituting the second coordination sphere to a ligated metal ion in the first coordination sphere. ${ }^{[5]}$ The chemical entities in the second coordination sphere can consist of ionic or molecular receptors and even portions of a ligand backbone. A number of synthetic and naturally occurring macrocyclic receptors $^{[6]}$ e.g. cyclodextrins ${ }^{[7]}$ (CDs), crown ethers, ${ }^{[8]}$ calixarenes, ${ }^{[9]}$ cucubiturils, ${ }^{[10]}$ and cyclophanes, ${ }^{[11]}$ have been shown ${ }^{[4 a]}$ to act as efficient second-sphere ligands. In general, the first-sphere ligands generate second-sphere adducts by harnessing the entire range of noncovalent bonding interactions, e.g. electrostatic, hydrogen bonding, charge transfer, and van der Waals interactions. Second-sphere coordination has been shown to exercise significant influence upon various scientific phenomena, including biological recognition ${ }^{[12]}$ and supramolecular assembly. [13]

Beginning in the early 1980s, we sought ${ }^{[4 a]}$ to gain insight into the nature of second-sphere coordination by studying such interactions with TMCs. We found that a number of $\mathrm{Pt}, \mathrm{Rh}, \mathrm{Ir}, \mathrm{Cu}$, and Fe complexes generate second-sphere adducts with a variety of macrocyclic receptors, such as crown ethers, CDs, and cyclophanes. Our recent exploration ${ }^{[14]}$ of the second-sphere coordination chemistry of a series of gold complexes with CDs has led to an environmentally benign process for extracting gold, which avoids the use of toxic cyanide salts, commonly used in the mining and recovery of gold. In this review, we first of all discuss the secondsphere coordination chemistry of $\mathrm{Pt}, \mathrm{Rh}, \mathrm{Ir}$, $\mathrm{Cu}$, and $\mathrm{Fe}$ complexes. This discussion will be followed by an account of our recent foray into the second-sphere coordination chemistry of gold complexes.[14]

\section{Transition Metal Complexes as the First Coordination Sphere}

\subsection{Adduct Formation Involving Platinum Complexes}

Platinum complexes with $\mathrm{NH}_{3}$ groups as their first-sphere ligands can act ${ }^{[15]}$ as hydrogen bond donors, and are thus ideal entities for forming second-sphere adducts with a series of hydrogen bond acceptors. Our initial investigations of these TMCs started with the examining of adducts of the monoammine complexes [trans$\left.\operatorname{Pt}\left(\mathrm{PR}_{3}\right) \mathrm{Cl}_{2}\left(\mathrm{NH}_{3}\right)\right](\mathrm{R}=\mathrm{Me}$ or Et $)$ with [18] crown-6 (18C6). The adducts crystallized with a 2:1 (TMC:18C6) stoichiometry. In the X-ray crystal structure ${ }^{[16]}$ of $[\{$ trans$\left.\left.\mathrm{Pt}\left(\mathrm{PR}_{3}\right) \mathrm{Cl}_{2}\left(\mathrm{NH}_{3}\right)\right\}_{2} \cdot 18 \mathrm{C} 6\right], \quad 18 \mathrm{C} 6$ adopts the all-gauche conformation with its six oxygen atoms hydrogen bonded to the two $\mathrm{NH}_{3}$ ligands of the Pt complex. When the second-sphere ligand was replaced by dibenzo[18]crown-6 (DB18C6), a 1:1 adduct was formed between [trans- $\mathrm{Pt}\left(\mathrm{PR}_{3}\right)$ $\left.\mathrm{Cl}_{2}\left(\mathrm{NH}_{3}\right)\right](\mathrm{R}=\mathrm{Me}$ or Et) and DB18C66. The crystallographic analysis of the adduct $\left[\left\{\right.\right.$ trans $\left.\left.-\mathrm{Pt}\left(\mathrm{PMe}_{3}\right) \mathrm{Cl}_{2}\left(\mathrm{NH}_{3}\right)\right\} \cdot \mathrm{DB} 18 \mathrm{C} 6\right]$ revealed (Fig. 1) that the two benzo rings of DB18C6 are folded away from the Pt-N vector and the six oxygen atoms form three bifurcated $[\mathrm{N}-\mathrm{H} \cdots \mathrm{O}]$ hydrogen bonds with the $\mathrm{NH}_{3}$ ligand. $[\mathrm{C}-\mathrm{H} \cdots \mathrm{Cl}-\mathrm{Pt}]$ Hydrogen bonding provides additional stabilization in the case of both the 18C6 and DB18C6 adducts. [N-H...O] Hydrogen bonding, however, does not always characterize the second-sphere adducts involving Pt com- 


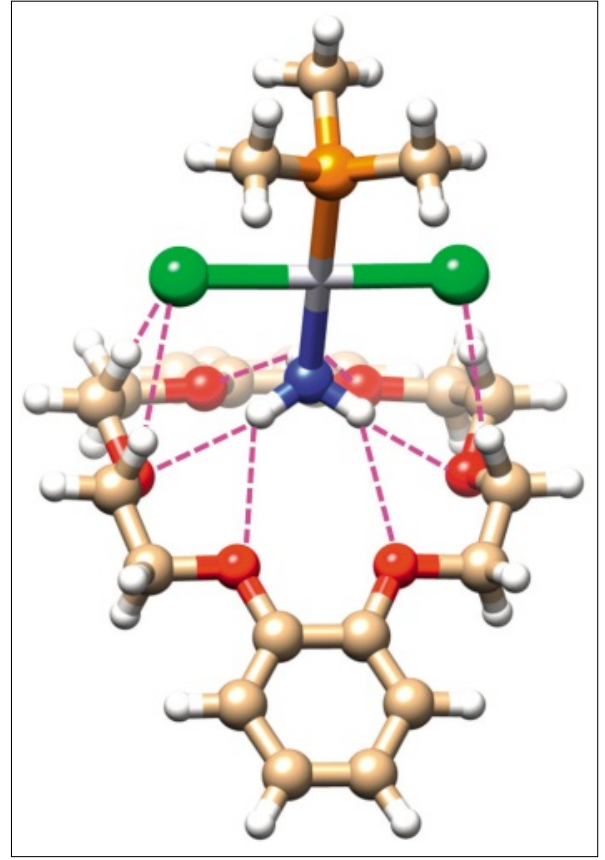

Fig. 1. The X-ray crystal structure of [\{trans$\left.\left.\mathrm{Pt}\left(\mathrm{PMe}_{3}\right) \mathrm{Cl}_{2}\left(\mathrm{NH}_{3}\right)\right\} \bullet \mathrm{DB} 18 \mathrm{C} 6\right]$. C, tan; $\mathrm{H}$, white; $\mathrm{O}$, red; N, blue; Pt, silver; $\mathrm{P}$, yellow; $\mathrm{Cl}$, green. Magenta lines indicate hydrogen bonds.

plexes with $\mathrm{NH}_{3}$ ligands. The X-ray crystal structure (Fig. 2) of the 1:1 adduct [ $\{$ trans$\left.\left.\mathrm{Pt}\left(\mathrm{PMe}_{3}\right) \mathrm{Cl}_{2}\left(\mathrm{NH}_{3}\right)\right\} \bullet \beta-\mathrm{CD}\right] \quad$ indicates, ${ }^{[17]}$ for instance, that the $\mathrm{PMe}_{3}$ ligand of [trans$\left.\mathrm{Pt}\left(\mathrm{PMe}_{3}\right) \mathrm{Cl}_{2}\left(\mathrm{NH}_{3}\right)\right]$ is inserted into the $\beta$-CD cavity, as well as being bound to the primary face of the $\beta$-CD torus. The $\mathrm{NH}_{3}$ ligand is free of any hydrogen bonds to the $\beta$-CD. The two $\mathrm{Cl}$ atoms are involved in the $[\mathrm{C}-\mathrm{H} \cdots \mathrm{Cl}-\mathrm{Pt}]$ hydrogen bonding with the $\mathrm{H}-6$ protons on two of the $\mathrm{CH}_{2}$ groups of $\beta$-CD.

Pt complexes with two or more $\mathrm{NH}_{3}$ ligands should have even more opportunities to hydrogen bond with second-sphere ligands and this outcome is indeed the one observed. While [trans-Pt $\left(\mathrm{NH}_{3}\right)_{2} \mathrm{Cl}_{2}$ ] and 18C6 form a highly insoluble polymeric superstructure with a 1:1 stoichiometry, the isomeric $\left[\right.$ cis- $\left.\mathrm{Pt}\left(\mathrm{NH}_{3}\right)_{2} \mathrm{Cl}_{2}\right]-$ the antitumor drug Cisplatin - generates ${ }^{[18]}$ a sol-

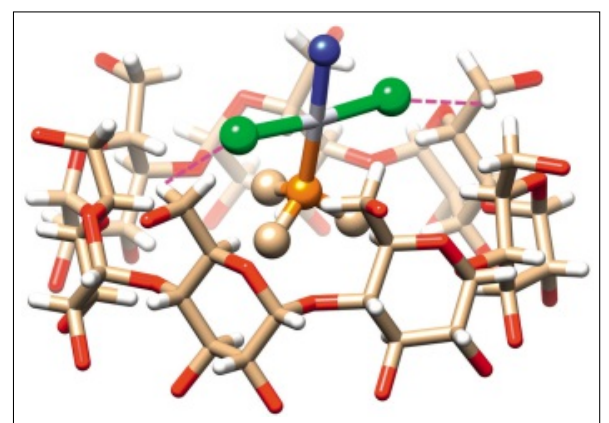

Fig. 2. The $\mathrm{X}$-ray crystal structure of [\{trans$\left.\mathrm{Pt}\left(\mathrm{PMe}_{3}\right) \mathrm{Cl}_{2}\left(\mathrm{NH}_{3}\right)\right\} \bullet \beta-\mathrm{CD}$. C, tan; $\mathrm{H}$, white; $\mathrm{O}$, red; N, blue; Pt, silver; P, yellow; $\mathrm{Cl}$, green. Magenta lines indicate hydrogen bonds. uble $2: 1$ adduct $\left[\left\{\right.\right.$ cis- $\left.\left.\mathrm{Pt}\left(\mathrm{NH}_{3}\right)_{2} \mathrm{Cl}_{2}\right\} \cdot 18 \mathrm{C} 6\right]$ with 18C6. The cis-oriented $\mathrm{NH}_{3}$ ligands on $\left[\right.$ cis- $\left.\mathrm{Pt}\left(\mathrm{NH}_{3}\right)_{2} \mathrm{Cl}_{2}\right]$ are all $[\mathrm{N}-\mathrm{H} \cdots \mathrm{O}]$ hydrogen bonded to respective faces of 18C6. An analog of Cisplatin, cyclobutane-1,1-dicarboxylatodiammineplatinum(II) ([Pt( $\left.\left.\mathrm{NH}_{3}\right)_{2}(\mathrm{CBDCA})\right]$, Carboplatin) forms ${ }^{[19]}$ a $1: 1$ adduct $\left[\left\{\mathrm{Pt}\left(\mathrm{NH}_{3}\right)_{2}\right.\right.$ $(\mathrm{CBDCA})\} \cdot \alpha-\mathrm{CD}]$ with $\alpha$-CD in aqueous solution as well as in the solid state. The X-ray crystal structure reveals (Fig. 3 ) that the adduct is stabilized by two [N-H… $\mathrm{O}]$ hydrogen-bonding interactions between the two $\mathrm{NH}_{3}$ ligands with the secondary hydroxyl groups on $\alpha-\mathrm{CD}$, as well as hydrophobic interactions resulting from the penetration of the cyclobutane ring of the complex into the $\alpha$-CD cavity. The fully $\mathrm{NH}_{3}$-ligated $\mathrm{Pt}$ complex $\left[\mathrm{Pt}\left(\mathrm{NH}_{3}\right)_{4}\right]\left[\mathrm{PF}_{6}\right]_{2}$ has also been found ${ }^{[20]}$ to interact with macropolycyclic crown ether bisamide- and macrobicyclic polyether receptors, forming $2: 1$ and $1: 1$ adducts, respectively. X-Ray crystallography of these adducts reveals that the $[\mathrm{N}-\mathrm{H} \cdots \mathrm{O}]$ hydrogen bonding indeed stabilizes both superstructures. We also discovered ${ }^{[16 b, 21]}$ that $\left[\mathrm{Pt}\left(\mathrm{H}_{2} \mathrm{NCH}_{2} \mathrm{CH}_{2} \mathrm{NH}_{2}\right)_{2}\right]\left[\mathrm{PF}_{6}\right]_{2}$, containing bidentate ligands, forms a $1: 1$ adduct $\left[\left\{\mathrm{Pt}\left(\mathrm{H}_{2} \mathrm{NCH}_{2} \mathrm{CH}_{2} \mathrm{NH}_{2}\right)_{2}\right\} \bullet 18 \mathrm{C} 6\right]_{n}^{2 \mathrm{n}+}$ with 18C6. The single-crystal X-ray structure of this adduct reveals an extended polymeric superstructure in which only one $\mathrm{H}$ atom of each $\mathrm{NH}_{2}$ group and only four crown ether $\mathrm{O}$ atoms are involved in hydrogen bonding.

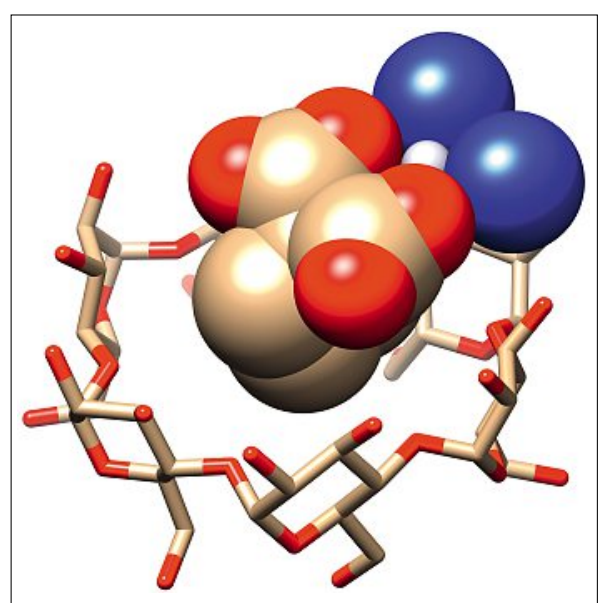

Fig. 3. The $X$-ray crystal structure of $\left[\left\{\mathrm{Pt}\left(\mathrm{NH}_{3}\right)_{2}(\mathrm{CBDCA})\right\} \bullet \alpha-\mathrm{CD}\right] . \mathrm{C}, \tan ; \mathrm{O}$, red; $\mathrm{N}$, blue; $\mathrm{Pt}$, silver.

In addition to hydrogen bonding, $\pi-\pi$ interactions also play an important role in stabilizing second-sphere adducts. We stumbled across an example ${ }^{[22]}$ of this phenomenon in the $\mathrm{Pt}$ complex $[\mathrm{Pt}(\mathrm{bpy})$ $\left.\left(\mathrm{NH}_{3}\right)_{2}\right]\left[\mathrm{PF}_{6}\right]_{2}$ with $\mathrm{NH}_{3}$ and 2,2-bipyridine (bpy) ligands. A series of 1:1 adducts has been obtained from $\left[\mathrm{Pt}(\mathrm{bpy})\left(\mathrm{NH}_{3}\right)_{2}\right]$ $\left[\mathrm{PF}_{6}\right]_{2}$ with $\mathrm{DB} 3 n \mathrm{C} n(n=8,10$, and 11$)$ as well as with dinaphtho[30]crown-10 (DN30C10). In essence, the major secondsphere coordination interactions of the platinum-based adducts discussed in this section stem from (i) $[\mathrm{N}-\mathrm{H}$...O $]$ hydrogen bonding between $\mathrm{NH}_{3}$ ligands and oxygen atoms on the U-shaped crown ether, (ii) the charge-dipole interactions between the 2+ complex and the oxygen atoms, as well as (iii) the $\pi-\pi$ charge transfer interaction between the byp ligands and benzo or naphtho ring systems.

\subsection{Adduct Formation Involving Rhodium Complexes}

Two 1+ rhodium(I) complexes $\left[\mathrm{Rh}(\mathrm{cod})\left(\mathrm{NH}_{3}\right)_{2}\right]^{+}(\mathrm{cod}=1,5$-cyclooctadiene) and $\left[\mathrm{Rh}(\mathrm{nbd})\left(\mathrm{NH}_{3}\right)_{2}\right]^{+}(\mathrm{nbd}=$ norbornadiene) with two cis- $\mathrm{NH}_{3}$ ligands were selected ${ }^{[23]}$ as another class of first-sphere TMC candidates on account of their potential hydrogen bonding with second-sphere ligands. $\left[\mathrm{Rh}(\mathrm{cod})\left(\mathrm{NH}_{3}\right)_{2}\right]^{+}$with $\mathrm{DB} 3 n \mathrm{Cn}$ $\left(n=7,8\right.$, and 10) forms ${ }^{[23]}$ the $1: 1$ adducts $\left[\left\{\mathrm{Rh}(\mathrm{cod})\left(\mathrm{NH}_{3}\right)_{2}\right\} \cdot \mathrm{DB} 21 \mathrm{C} 7\right]^{+},[\{\mathrm{Rh}(\mathrm{cod})$ $\left.\left.\left(\mathrm{NH}_{3}\right)_{2}\right\} \bullet \mathrm{DB} 24 \mathrm{C} 8\right]^{+}$, and $\left[\left\{\mathrm{Rh}(\mathrm{cod})\left(\mathrm{NH}_{3}\right)_{2}\right\}\right.$ -DB30C10 $]^{+}$, while $\left[\mathrm{Rh}(\mathrm{nbd})\left(\mathrm{NH}_{3}\right)_{2}\right]^{+}$ with $\mathrm{DB} 24 \mathrm{C} 8$ results ${ }^{[23 a]}$ in a 1:1 adduct $\left[\left\{\mathrm{Rh}(\mathrm{nbd})\left(\mathrm{NH}_{3}\right)_{2}\right\} \bullet \mathrm{DB} 24 \mathrm{C} 8\right]^{+}$. The superstructures of these adducts have been confirmed by X-ray crystallography. Their solid-state superstructures reveal that the major stabilizing features aiding and abetting second-sphere coordination in these adducts are $[\mathrm{N}-\mathrm{H} \cdots \mathrm{O}]$ hydrogen bonds between the $\mathrm{NH}_{3}$ ligands and the $\mathrm{O}$ atoms on the crown ethers on top of additional $[\mathrm{C}-\mathrm{H} \cdots \pi]$ interactions between allylic and vinylic $\mathrm{C}-\mathrm{H}$ groups with benzene rings in the second-sphere receptor. In common with $\left[\left\{\mathrm{Pt}\left(\mathrm{NH}_{3}\right)_{2}(\mathrm{CBDCA})\right\} \bullet \alpha-\mathrm{CD}\right]$, a $1: 1$ adduct $\left[\left\{\mathrm{Rh}(\mathrm{cod})\left(\mathrm{NH}_{3}\right)_{2}\right\} \bullet \alpha-\mathrm{CD}\right]^{+}$ between $\left[\mathrm{Rh}(\mathrm{cod})\left(\mathrm{NH}_{3}\right)_{2}\right]^{+}$and $\alpha$-CD was obtained and characterized ${ }^{[5,24]}$ by X-ray diffraction. The solid-state superstructure (Fig. 4) reveals that the boat-shaped cod ligand is embedded partially inside the

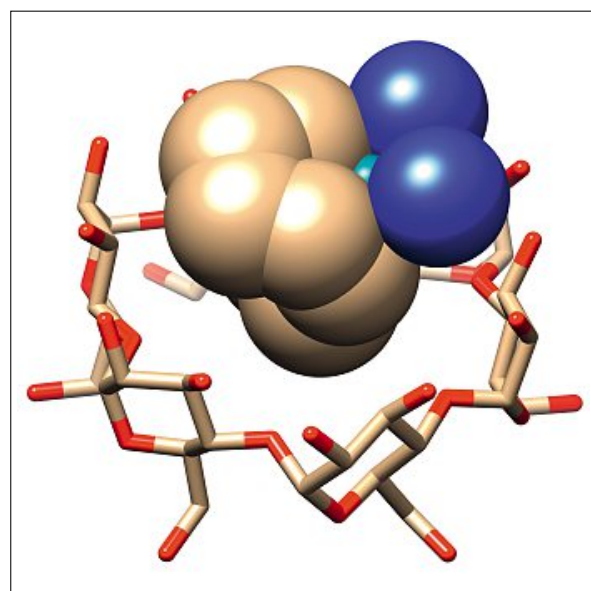

Fig. 4. The $\mathrm{X}$-ray crystal structure of [ $[\mathrm{Rh}(\mathrm{cod})$ $\left.\left.\left(\mathrm{NH}_{3}\right)_{2}\right\} \bullet \alpha-\mathrm{CD}\right]^{+}$. C, tan; O, red; N, blue; Rh, light blue. 
$\alpha$-CD cavity, while the tilted orientation of the complex facilitates the formation of the $[\mathrm{N}-\mathrm{H} \cdots \mathrm{O}]$ hydrogen bonds between two $\mathrm{NH}_{3}$ ligands and four of the secondary hydroxyl groups on the $\alpha$-CD torus.

\subsection{Adduct Formation Involving Iridium, Copper, and Iron \\ Complexes}

The iridium complex $[$ trans- $[\operatorname{Ir}(\mathrm{CO})$ $\left.\left(\mathrm{CH}_{3} \mathrm{CN}\right)\left(\mathrm{PPh}_{3}\right)_{2}\right]\left[\mathrm{PF}_{6}\right]$ forms ${ }^{[25]}$ a $2: 1$ adduct $\left[\left\{\text { trans }-\mathrm{Ir}(\mathrm{CO})\left(\mathrm{CH}_{3} \mathrm{CN}\right)\left(\mathrm{PPh}_{3}\right)_{2}\right\}_{2}\right.$ $\cdot 18 \mathrm{C} 6]^{2+}$ with $18 \mathrm{C} 6$. The solid-state superstructure of the adduct shows that stabilization of the superstructure arises mainly from $[\mathrm{C}-\mathrm{H} \cdots \mathrm{O}]$ hydrogen bonding between $\mathrm{CH}_{3} \mathrm{CN}$ ligands and $\mathrm{O}$ atoms on $18 \mathrm{C} 6$.

The copper complex $\left[\mathrm{Cu}\left(\mathrm{NH}_{3}\right)_{4}\right.$ $\left.\left(\mathrm{H}_{2} \mathrm{O}\right)\right]^{2+}$, i.e. the 'cuprammonium' ion, was examined ${ }^{[16 \mathrm{~b}]}$ as a potential first-sphere TMC. On mixing an aqueous solution of $\left[\mathrm{Cu}\left(\mathrm{NH}_{3}\right)_{4}\left(\mathrm{H}_{2} \mathrm{O}\right)\right]\left[\mathrm{PF}_{6}\right]_{2}$ with $18 \mathrm{C} 6$, a $1: 1$ adduct $\left[\left\{\mathrm{Cu}\left(\mathrm{NH}_{3}\right)_{4}\left(\mathrm{H}_{2} \mathrm{O}\right)\right\} \bullet 18 \mathrm{C} 6\right]_{\mathrm{n}}\left[\mathrm{PF}_{6}\right]_{2 \mathrm{n}}$ precipitates in high yield. Single crystal X-ray analysis reveals (Fig. 5) that this adduct has a polymeric superstructure, which is stabilized by [N-H $\cdots \mathrm{O}]$ hydrogen bonding of two axial- $\mathrm{NH}_{3}$ ligands of the complex with the $\mathrm{O}$ atoms of 18C6. The stability of this adduct facilitates a bulk scale approach (Fig. 6) to the separation of $\left[\mathrm{Cu}\left(\mathrm{NH}_{3}\right)_{4}\left(\mathrm{H}_{2} \mathrm{O}\right)\right]^{2+}$ from other competing ions such as $\left[\mathrm{Co}\left(\mathrm{NH}_{3}\right)_{6}\right]^{3+}$.

In more recent times, a tetracationic cyclophane has been shown ${ }^{[11]}$ to accommodate a ferrocene molecule inside its cavity, affording a 1:1 adduct. Singlecrystal X-ray analysis reveals (Fig. 7) that $\pi-\pi$ stacking interactions between the $\pi$-electron rich cyclopentadienyl units in the ferrocene guest and the $\pi$-electron poor bipyridinium units in the host cyclophane are most likely the major driving force for the formation of this adduct.

\section{Second-Sphere Coordination Chemistry of Gold Complexes with CDs}

Although the coordination chemistry of Pt- and Rh-complexes with various second-sphere ligands has been explored,[4a] their associated noncovalent bonding interactions involving gold complexes have remained unknown until our recent serendipitous discovery[14] that square-planar tetrahaloaurate anions $\left(\left[\mathrm{AuX}_{4}\right]^{-}, \mathrm{X}=\mathrm{Cl}\right.$, $\mathrm{Br})$ are included inside the cavities of $\alpha$-, $\beta$-, and $\gamma$-CDs.

\subsection{Discovery of Second-Sphere Adduct between Potassium Tetrabromoaurate and $\alpha-C D$}

Our accidental discovery ${ }^{[26]}$ of the formation of CD-MOFs from alkali metal

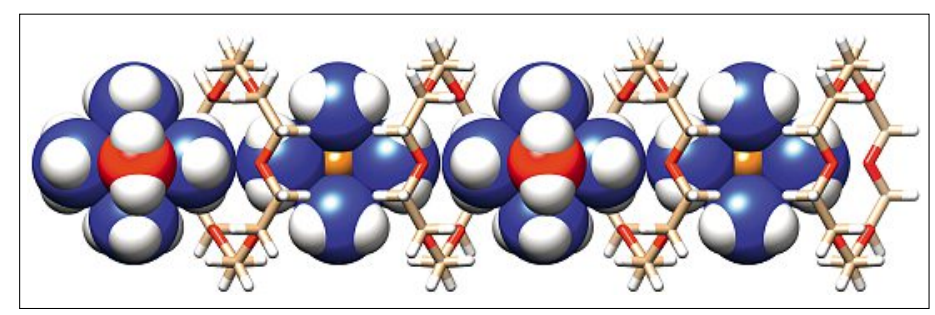

Fig. 5. The X-ray crystal structure of $\left[\left\{\mathrm{Cu}\left(\mathrm{NH}_{3}\right)_{4}\left(\mathrm{H}_{2} \mathrm{O}\right)\right\}\right.$ -18C6] $]_{n}\left[\mathrm{PF}_{6}\right]_{2 \mathrm{n}}$. C, tan; $\mathrm{H}$, white; O, red; $\mathrm{N}$, blue; $\mathrm{Cu}$, gold.

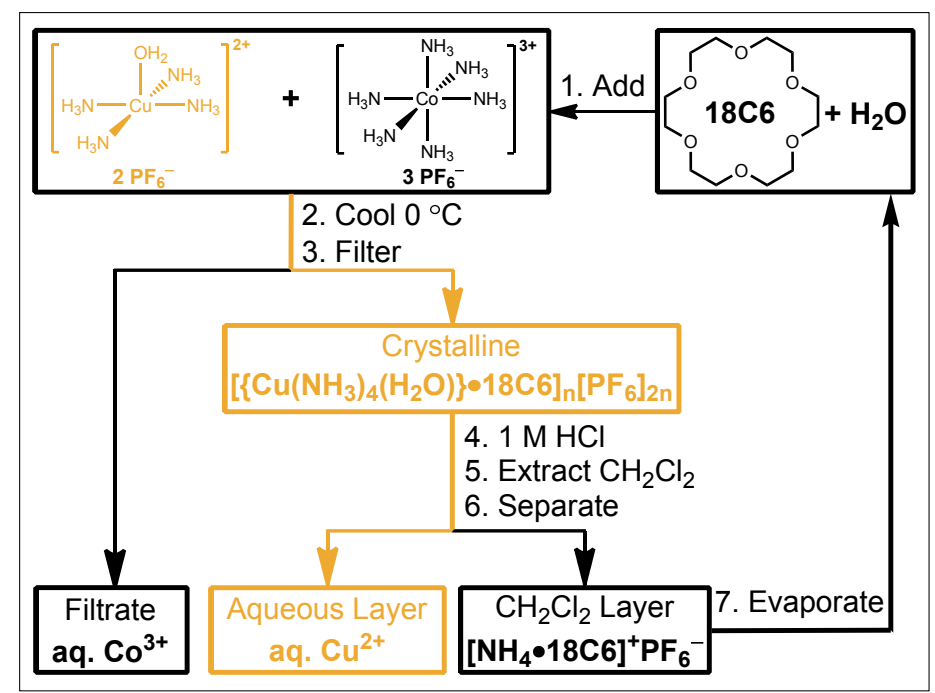

Fig. 6. A flow chart for the separation of $\mathrm{Cu}^{2+}$ from $\mathrm{Co}^{3+}$.

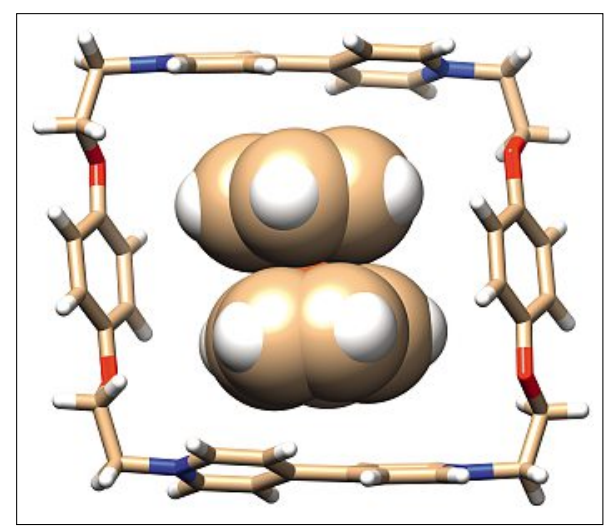

Fig. 7. The X-ray crystal structure of a 1:1 adduct between ferrocene and a synthetic molecular square. $\mathrm{C}$, tan; $\mathrm{H}$, white; $\mathrm{O}$, red; $\mathrm{N}$, blue; $\mathrm{Fe}$, orange.

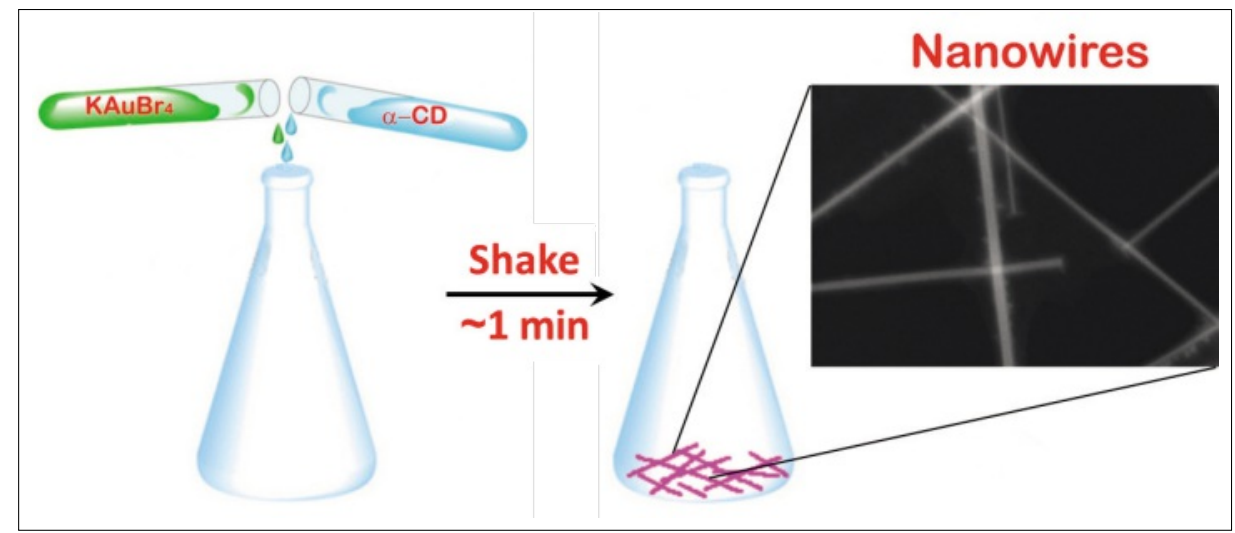

Fig. 8. Formation of crystalline nanowires of the co-precipitated $\alpha \bullet \mathrm{Br}$ from $\mathrm{KAuBr}_{4}(0.005 \mathrm{~mol} / \mathrm{L})$ and $\alpha-\mathrm{CD}(0.01 \mathrm{~mol} / \mathrm{L})$.
$\left(\mathrm{Na}^{+}, \mathrm{K}^{+}, \mathrm{Rb}^{+}\right.$, and $\left.\mathrm{Cs}^{+}\right)$salts and $\gamma-\mathrm{CD}$ encouraged us to extend the nature of the salt to $\mathrm{KAuX}_{4}$ with its unique squareplanar anion $\left[\mathrm{AuX}_{4}\right]^{-}$, as well as to $\alpha$ - and $\beta$-CDs. When adding aqueous solutions of $\mathrm{KAuCl}_{4}$ and $\mathrm{KAuBr}_{4}$ dropwise into solutions of $\alpha-, \beta$-, or $\gamma$-CDs in water, we found that, only in the case of $\mathrm{KAuBr}_{4}$ and $\alpha-\mathrm{CD}$, does a shiny pale brown precipitate form (Fig. 8) immediately while all the other five solutions remain clear. This phenomenon, which is reminiscent ${ }^{[16 b]}$ of the co-precipitation (Fig. 5) of the secondsphere adduct $\left[\left\{\mathrm{Cu}\left(\mathrm{NH}_{3}\right)_{4}\left(\mathrm{H}_{2} \mathrm{O}\right)\right\} \bullet 18 \mathrm{C} 6\right]_{\mathrm{n}}$ $\left[\mathrm{PF}_{6}\right]_{2 \mathrm{n}}$ from an aqueous solution containing $\left[\mathrm{Cu}\left(\mathrm{NH}_{3}\right)_{4}\left(\mathrm{H}_{2} \mathrm{O}\right)\right]\left[\mathrm{PF}_{6}\right]_{2}$ and $18 \mathrm{C} 6$, suggests a novel approach to the sequestration and isolation of gold. In order to obtain further insight into the microstructure of the shiny pale brown precipitate, an as- 
prepared sample was subjected to scanning electron microscopy (SEM) and transmission electron microscopy (TEM), in addition to selected area electron diffraction (SAED) analyses. The SEM image (Fig. 9a) reveals the morphology of thin needles with extremely high aspect ratios. The TEM images (Fig. 9b) show that these needles have diameters of several hundreds of nanometers and lengths on the order of micrometers. SAED patterns are also consistent with the crystalline nature of these needles.

Single crystals, suitable for X-ray crystallography, were obtained by slow vapor diffusion of ${ }^{i} \mathrm{PrOH}$ into a dilute aqueous solution of $\mathrm{KAuBr}_{4}$ and $\alpha$-CD. The solid-state superstructure (Fig. 10) revealed a 1:2 second-sphere adduct - namely, $\operatorname{KAuBr}_{4} \bullet(\alpha-\mathrm{CD})_{2}$ which will now be referred to as $\alpha \cdot \mathbf{B r}$ - with a polymeric $\left\{\left[\mathrm{K}\left(\mathrm{OH}_{2}\right)_{6}\right]\left[\mathrm{AuBr}_{4}\right] \subset(\alpha-\mathrm{CD})_{2}\right\}_{\mathrm{n}}$ chain superstructure, generated from two first-sphere complex ions $\left[\mathrm{K}\left(\mathrm{OH}_{2}\right)_{6}\right]^{+}$and $\left[\mathrm{AuBr}_{4}\right]^{-}$and two $\alpha$-CD second-sphere ligands. The $\alpha$-CDs are stacked in the crystal and held together by [O-H...O] hydrogen bonding in a head-to-head and tail-to-tail alternating fashion to form channels. The space between the hydroxyl groups on the secondary $\left(2^{\circ}\right)$ faces of the $\alpha$-CDs acts as a second-sphere cavity (Fig. 10 a, Cavity 2) which is filled with a distorted octahedrally coordinated hexa-aqua $\mathrm{K}^{+}$ion $\left(\left[\mathrm{K}\left(\mathrm{OH}_{2}\right)_{6}\right]^{+}\right)$with quite short $\mathrm{K}-\mathrm{O}$ distances. ${ }^{[27]}$ To the best of our knowledge, this situation is a rare example, showing that such a fully-hydrated $\mathrm{K}^{+}-$acting as a hydrophilic first-sphere complex - is second-sphere coordinated in a cavity which is generally considered to be hydrophobic. There are many examples ${ }^{[4 a, 28]}$ of secondsphere adduct formation involving aqua ligands in the literature. In contrast, another second-sphere cavity (Fig. 10a, Cavity 1) between the hydroxyl groups on the primary $\left(1^{\circ}\right)$ faces of the $\alpha$-CDs is occupied by the square-planar $\left[\mathrm{AuBr}_{4}\right]^{-}$anion which is oriented in a nearly vertical fashion inside the $\alpha$-CD channel with a tilt angle of $\sim 9^{\circ}$ with respect to the $c$-crystallographic axis. Although the $\mathrm{H}$ atoms on the $\mathrm{H}_{2} \mathrm{O}$ molecules of the $\left[\mathrm{K}\left(\mathrm{OH}_{2}\right)_{6}\right]^{+}$ions defy refinement, the rather short distances between the axial $\mathrm{Br}$ and $\mathrm{O}$ atoms suggest the presence of stabilizing $[\mathrm{O}-\mathrm{H} \cdots \mathrm{Br}-\mathrm{Au}]$ hydrogen bonds directed along the $c$-axis. These hydrogen bonds, coupled with [O-H...O-H] hydrogen bonding and van der Waals interactions between $\left[\mathrm{K}\left(\mathrm{OH}_{2}\right)_{6}\right]^{+}$and the hydroxyl groups on secondary faces of the $\alpha$-CDs, contribute to the stabilization of the second-sphere adduct of $\left[\mathrm{K}\left(\mathrm{OH}_{2}\right)_{6}\right]^{+}$and $\alpha$-CDs, while the $[\mathrm{C}-\mathrm{H} \cdots \mathrm{Br}-\mathrm{Au}]$ hydrogen bonds (2.92-3.19 $\AA$ ) between $\left[\mathrm{AuBr}_{4}\right]^{-}$and twelve H-5 and H-6 atoms on the primary faces of $\alpha$-CDs provide the

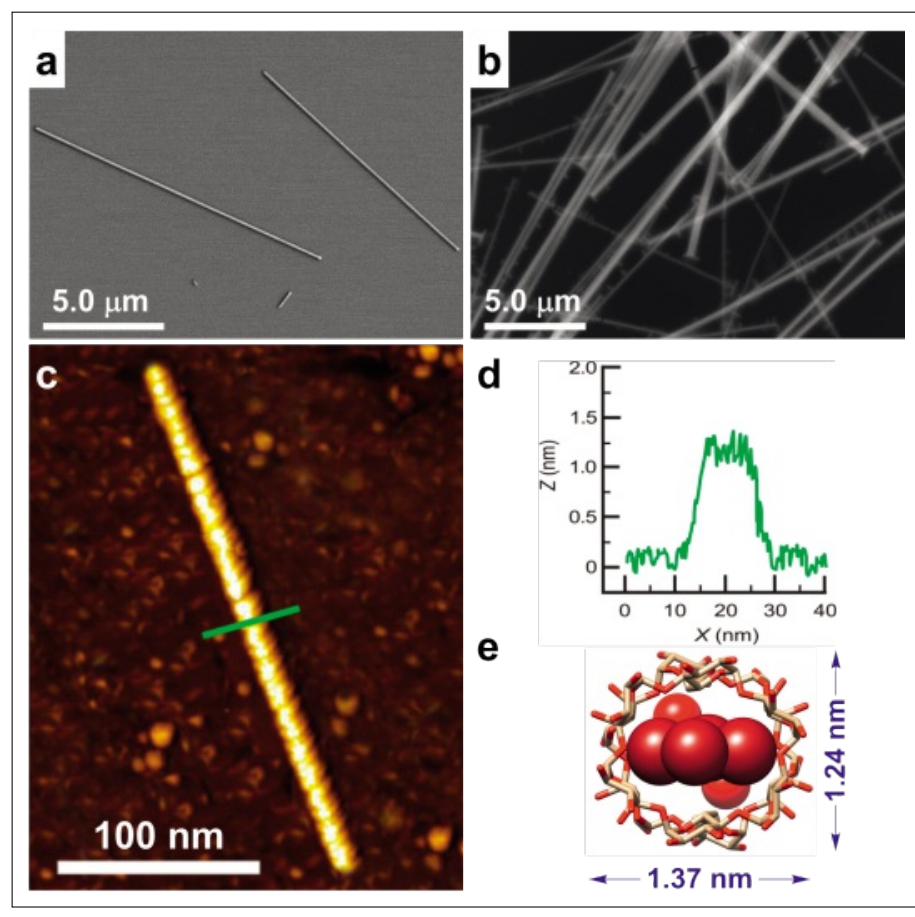

Fig. 9. (a) SEM and (b) TEM images of a coprecipitated sample of $\alpha \bullet \mathrm{Br}$. (c-e) AFM analysis of $\alpha \cdot \mathrm{Br}$ on a mica surface.

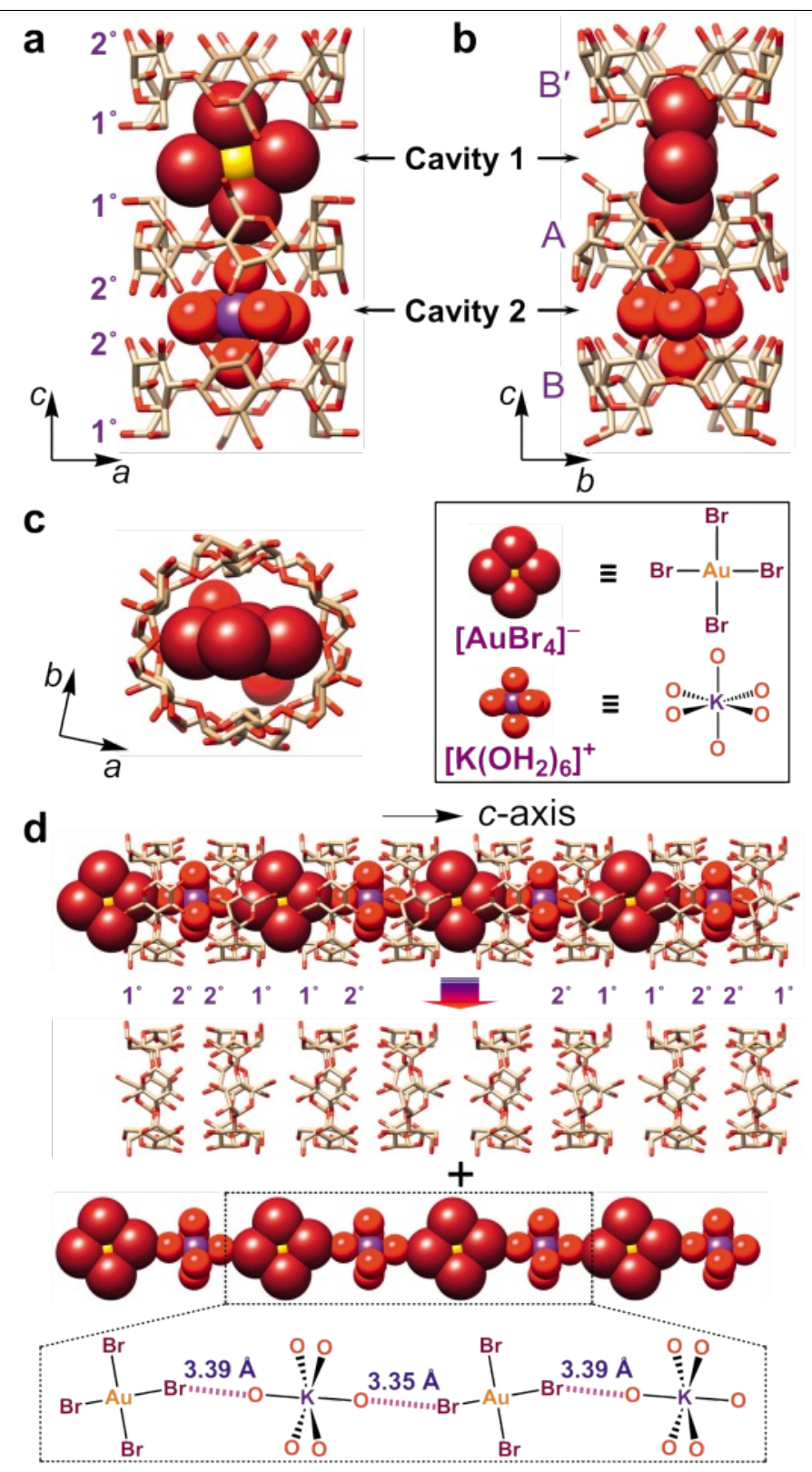

Fig. 10. The singlecrystal X-ray structure of $\alpha \cdot \mathrm{Br}$. C, tan; O, red; $\mathrm{Br}$, brown; $\mathrm{Au}$, yellow; K, purple. Magenta lines indicate hydrogen bonds. 
driving force for the second-sphere coordination of $\left[\mathrm{AuBr}_{4}\right]^{-}$with $\alpha$-CDs. Therefore, the two second-sphere adducts line up in a manner with alternating positive and negative charges surrounded by an outer sheath-like organic nanotube stabilized by electrostatic interactions associated with the inner polyionic chain. The high level of consistency between the experimental powder X-ray diffraction (PXRD) pattern of the as-synthesized co-precipitate and the simulated pattern derived from singlecrystal XRD data confirmed the purity and the identity of the crystalline phases in both crystals and co-precipitates.

Atomic force microscopy (AFM) was also used to investigate the superstructure of the polymeric adduct. AFM images (Fig. 9c-e) of a spin-coated sample revealed the efficiency and specificity of the self-assembly process by observing discrete nano-assemblies with lengths of several hundreds of nanometers and heights of $\sim 1.3 \mathrm{~nm}$, a dimension which is consistent with the outer diameter $(\sim 1.4 \mathrm{~nm})$ of $\alpha$-CD.

\subsection{Second-Sphere Adducts of Potassium Tetrahaloaurates with $\alpha-, \beta-$, and $\gamma-C D s$}

The uniqueness of the spontaneous co-precipitation of $\alpha \cdot \mathbf{B r}$ prompted us to find out more about what causes the differences in the supramolecular behavior between the $\alpha \cdot \mathbf{B r}$ adduct and the other five possible combinations of adducts involving $\mathrm{KAuX}_{4}$ and $\mathrm{CDs}$. We were able to obtain single crystals of all five combinations of these adducts. X-Ray crystallography reveals (Fig. 11) that all these combinations lead to second-sphere adducts $\mathrm{KAuCl}_{4} \bullet(\alpha-\mathrm{CD})_{2}, \mathrm{KAuBr}_{4} \bullet(\beta-\mathrm{CD})_{2}$, $\mathrm{KAuCl}_{4} \bullet(\beta-\mathrm{CD})_{2}, \quad \mathrm{KAuBr}_{4} \bullet(\gamma-\mathrm{CD})_{3}$, and $\mathrm{KAuCl}_{4} \bullet(\gamma-\mathrm{CD})_{3}-$ that is, $\alpha \bullet \mathbf{C l}, \beta \bullet \mathbf{B r}, \beta \bullet \mathbf{C l}$, $\boldsymbol{\gamma} \mathbf{B r}$, and $\boldsymbol{\gamma} \mathbf{C l}$, respectively. Unlike $\alpha \cdot \mathbf{B r}$, which has a highly compact superstructure with second-sphere coordinated $\left.\left[\mathrm{K}_{(} \mathrm{OH}_{2}\right)_{6}\right]^{+}$and $\left[\mathrm{AuBr}_{4}\right]^{-}$interacting inside the channels, these other five adducts constitute 'bamboo'-like superstructures with isolated empty 'capsules' formed between the $\left[\mathrm{AuX}_{4}\right]^{-}$ions, which are coordinated in a second-sphere fashion to the primary hydroxyl faces of the CDs by means of $[\mathrm{C}-\mathrm{H} \cdots \mathrm{X}-\mathrm{Au}]$ hydrogen bonds, while the $\mathrm{K}^{+}$ions are located outside the channels. Although the $\mathrm{Au}-\mathrm{Cl}$ bond length in $\alpha \cdot \mathbf{C l}$ is only $0.15 \AA$ shorter than the $\mathrm{Au}-\mathrm{Br}$ distance in $\alpha \cdot \mathbf{B r}$, the $\mathrm{K}^{+}$ions in $\alpha \cdot \mathbf{C l}$ are not encapsulated inside the channels as in $\alpha \bullet \mathbf{B r}$. This observation indicates that the shorter $\mathrm{Au}-\mathrm{Cl}$ bonds curtail the formation of the longitudinal $[\mathrm{O}-\mathrm{H} \cdots \mathrm{Cl}-\mathrm{Au}]$ hydrogen bonds that would presumably facilitate the encapsulation of $\left[\mathrm{K}\left(\mathrm{OH}_{2}\right)_{6}\right]^{+}$and lead to the co-precipitation of the final adduct, $\alpha \cdot \mathbf{B r}$. The subtle differences between $\left[\mathrm{AuBr}_{4}\right]^{-}$ and $\left[\mathrm{AuCl}_{4}\right]^{-}$, however, do not change the

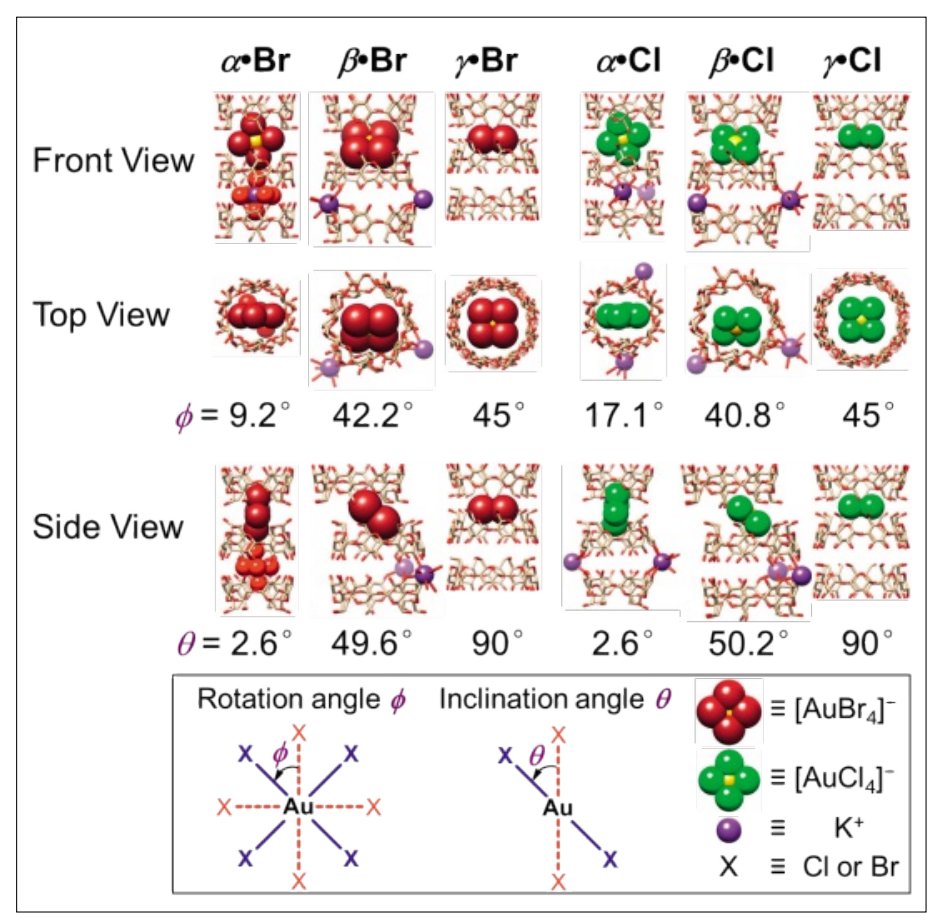

Fig. 11. Comparison of single-crystal X-ray structures of six second-sphere adducts of $\alpha \cdot \mathrm{Br}, \beta \bullet \mathrm{Br}, \gamma \cdot \mathrm{Br}$, $\alpha \bullet \mathbf{C l}, \beta \bullet \mathbf{C l}$, and $\gamma \bullet \mathbf{C l}$.

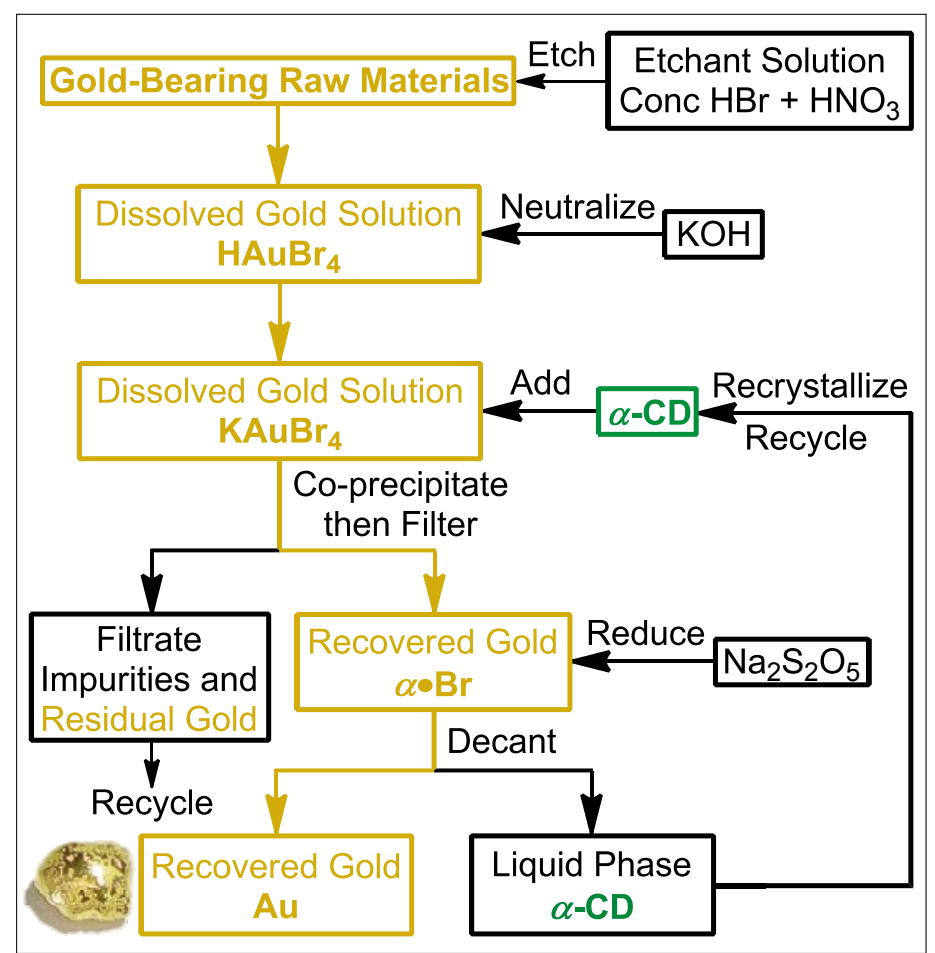

Fig. 12. A flow chart of the gold recovery process. fact that $\beta \bullet \mathbf{B r}$ and $\beta \bullet \mathbf{C l}$, as well as $\gamma \bullet \mathbf{B r}$ and $\boldsymbol{r} \mathbf{C l}$, are both isostructural. Although $\left[\mathrm{AuBr}_{4}\right]^{-}$and $\left[\mathrm{AuCl}_{4}\right]^{-}$are both able to form second-sphere adducts with $\alpha-, \beta$-, and $\gamma$-CDs, their orientations display a tendency to tilt (Fig. 11, side view) with increasing diameter of the CD torus. This observation can be described by (i) the rotation angle $\phi$ of $\left[\mathrm{AuX}_{4}\right]^{-}$viewed from the front, and (ii) the inclination angle $\theta$ of $[\mathrm{AuX}]^{-}$viewed from the side, along the principal axis of the CD tori. Presumably, $[\mathrm{C}-\mathrm{H} \cdots \mathrm{X}-\mathrm{Au}]$ hydrogen bonding provides the driving force for the specific orientation of $\left[\mathrm{AuX}_{4}\right]^{-}$in each adduct.

\subsection{Application of Second-Sphere Coordination to the Selective Isolation of Gold}

The highly selective co-precipitation of $\alpha$-CD towards trapping $\left[\mathrm{AuBr}_{4}\right]^{-}$illustrates its potential for the isolation of gold. Moreover, $\alpha$-CD - a cyclic oligosaccharide derived from starch - is non-toxic and environmentally benign. Further investigations have shown that $\alpha$-CD can capture $\left[\mathrm{AuBr}_{4}\right]^{-}$selectively and co-precipitate it as $\alpha \bullet \mathbf{B r}$ in aqueous solution, even in the presence of other isologues $\left[\mathrm{PtX}_{4}\right]^{2-}$ and $\left[\mathrm{PdX}_{4}\right]^{2-}(\mathrm{X}=\mathrm{Cl}, \mathrm{Br})$. In the wake of this fundamental research, a laboratory scale process (Fig. 12) for the highly selective 
extraction of gold has been devised based on the precipitation of the second-sphere adduct $\alpha \cdot \mathbf{B r}$. By merging this co-precipitation process with a more environmentally benign bromination leaching process, ${ }^{[29]}$ the development of a more scalable process for extracting gold is currently under investigation in our laboratory.

\section{Conclusions}

During the past 30 years, many second-sphere adducts between various firstsphere transition metal complexes and a broad range of natural and synthetic second-sphere ligands have been characterized. Recent progress on second-sphere coordination chemistry of gold complexes demonstrates the potential of secondsphere coordination for practical applications in the realm of sustainability, such as anion recognition leading to the selective isolation of gold. A major advantage of this process is that only mild conditions are required in order to afford adducts with welldefined and specific noncovalent bonding interactions. The vital role of serendipity in scientific discovery has now expressed itself in the realm of second-sphere coordination chemistry.

Received: March 30, 2014

[1] http://www.nobelprize.org/nobel_prizes/ chemistry/laureates/1913/.

[2] a) A. Werner, Ann. Chem. 1912, 386, 1; b) A. Werner, 'Neuere Anschauungen auf dem Gebiete der anorganischen Chemie', 3rd ed., Vieweg, Braunschweig 1913; c) A. Werner, Ber. Dtsch. Chem. Ges. 1912, 45, 121.

[3] a) D. J. Mercer, S. J. Loeb, Chem. Soc. Rev. 2010, 39, 3612; b) E. C. Constable, C. E. Housecroft, Chem. Soc. Rev. 2013, 42, 1429.

[4] a) H. M. Colquhoun, J. F. Stoddart, D. J. Williams, Angew. Chem. Int. Ed. Engl. 1986, 25, 487; b) D. Eaton, Rev. Chem. Intermed. 1988, 9, 201; c) J. F. Stoddart, R. Zarzycki, Rec. Trav. Chim. Pays-Bas 1988, 107, 515; d) F. M. Raymo, J. F. Stoddart, Chem. Ber. 1996, 129,
981; e) M. Rakowski DuBois, D. L. DuBois, Chem. Soc. Rev. 2009, 38, 62.

[5] D. R. Alston, P. R. Ashton, T. H. Lilley, J. F. Stoddart, R. Zarzycki, A. M. Z. Slawin, D. J. Williams, Carbohydr. Res. 1989, 192, 259.

[6] M. Formica, V. Fusi, M. Micheloni, R. Pontellini, P. Romani, Coord. Chem. Rev. 1999, 184, 347.

[7] F. Hapiot, S. Tilloy, E. Monflier, Chem. Rev. 2006, 106, 767.

[8] a) M. Mitewa, P. R. Bontchev, Coord. Chem. Rev. 1994, 135-136, 129; b) Z. Xiao Lian, D. I. Yoon, J. T. Hupp, Inorg. Chim. Acta 1995, 240, 285; c) J. W. Steed, Coord. Chem. Rev. 2001, 215, 171; d) J. M. Llinares, D. Powell, K. Bowman-James, Coord. Chem. Rev. 2003, 240, 57; e) I. Ando, Coord. Chem. Rev. 2004, 248, 185.

[9] J. L. Atwood, L. J. Barbour, M. J. Hardie, C. L. Raston, Coord. Chem. Rev. 2001, 222, 3.

[10] S.-Y. Kim, I.-S. Jung, E. Lee, J. Kim, S. Sakamoto, K. Yamaguchi, K. Kim, Angew. Chem. Int. Ed. 2001, 40, 2119.

[11] P. R. Ashton, C. G. Claessens, W. Hayes, J. F. Stoddart, S. Menzer, A. J. P. White, D. J. Williams, Angew. Chem. Int. Ed. Engl. 1995, 34, 1862 .

[12] S. E. Sherman, S. J. Lippard, Chem. Rev. 1987, 87, 1153.

[13] M. C. T. Fyfe, P. T. Glink, S. Menzer, J. F. Stoddart, A. J. P. White, D. J. Williams, Angew. Chem. Int. Ed. 1997, 36, 2068.

[14] Z. Liu, M. Frasconi, J. Lei, Z. J. Brown, Z. Zhu, D. Cao, J. Iehl, G. Liu, A. C. Fahrenbach, Y. Y. Botros, O. K. Farha, J. T. Hupp, C. A. Mirkin, J. F. Stoddart, Nat. Commun. 2013, 4, 1855.

[15] B. R. Cameron, S. S. Corrent, S. J. Loeb, Angew. Chem. Int. Ed. Engl. 1996, 34, 2689.

[16] a) H. M. Colquhoun, J. F. Stoddart, D. J. Williams, J. Chem. Soc. Chem. Commun. 1981, 847 ; b) H. M. Colquhoun, D. F. Lewis, J. F. Stoddart, D. J. Williams, J. Chem. Soc. Dalton Trans. 1983, 607.

[17] D. R. Alston, A. M. Z. Slawin, J. F. Stoddart, D. J. Williams, R. Zarzycki, Angew. Chem. Int. Ed. Engl. 1988, 27, 1184.

[18] D. R. Alston, J. F. Stoddart, D. J. Williams, J. Chem. Soc. Chem. Commun. 1985, 532.

[19] a) D. R. Alston, T. H. Lilley, J. F. Stoddart, J. Chem. Soc. Chem. Commun. 1985, 1600; b) D. R. Alston, A. M. Z. Slawin, J. F. Stoddart, D. J. Williams, J. Chem. Soc. Chem. Commun. 1985 , 1602.

[20] a) D. R. Alston, A. M. Z. Slawin, J. F. Stoddart, D. J. Williams, R. Zarzycki, Angew. Chem. Int. Ed. Engl. 1987, 26, 693; b) D. R. Alston, A. M. Z. Slawin, J. F. Stoddart, D. J. Williams, R. Zarzycki, Angew. Chem. Int. Ed. Engl. 1987, 26,692 .
[21] H. M. Colquhoun, J. F. Stoddart, D. J. Williams, J. Chem. Soc. Chem. Commun. 1981, 851.

[22] a) H. M. Colquhoun, J. F. Stoddart, D. J. Williams, J. B. Wolstenholme, R. Zarzycki, Angew. Chem. Int. Ed. Engl. 1981, 20, 1051; b) B. L. Allwood, H. M. Colquhoun, S. M. Doughty, F. H. Kohnke, A. M. Z. Slawin, J. F. Stoddart, D. J. Williams, R. Zarzycki, J. Chem. Soc. Chem. Commun. 1987, 1054; c) R. Ballardini, M. T. Gandolfi, V. Balzani, F. H. Kohnke, J. F. Stoddart, Angew. Chem. Int. Ed. Engl. 1988, 27, 692.

[23] a) H. M. Colquhoun, S. M. Doughty, J. F. Stoddart, D. J. Williams, Angew. Chem. Int. Ed. Engl. 1984, 23, 235; b) H. M. Colquhoun, S. M. Doughty, J. F. Stoddart, A. M. Z. Slawin, D. J. Williams, J. Chem. Soc. Dalton Trans. 1986, 1639.

[24] D. R. Alston, A. M. Z. Slawin, J. F. Stoddart, D. J. Williams, Angew. Chem. Int. Ed. Engl. 1985, 24, 786.

[25] H. M. Colquhoun, J. F. Stoddart, D. J. Williams, J. Am. Chem. Soc. 1982, 104, 1426.

[26] a) R. A. Smaldone, R. S. Forgan, H. Furukawa, J. J. Gassensmith, A. M. Z. Slawin, O. M. Yaghi, J. F. Stoddart, Angew. Chem. Int. Ed. 2010, 49, 8630 ; b) R. S. Forgan, R. A. Smaldone, J. J. Gassensmith, H. Furukawa, D. B. Cordes, Q. Li, C. E. Wilmer, Y. Y. Botros, R. Q. Snurr, A. M. Z. Slawin, J. F. Stoddart, J. Am. Chem. Soc. 2012, 134, 406; c) J. J. Gassensmith, H. Furukawa, R. A. Smaldone, R. S. Forgan, Y. Y. Botros, O. M. Yaghi, J. F. Stoddart, J. Am. Chem. Soc. 2011, 133, 15312; d) S. Han, Y. Wei, C. Valente, R. S. Forgan, J. J. Gassensmith, R. A. Smaldone, H. Nakanishi, A. Coskun, J. F. Stoddart, B. A. Grzybowski, Angew. Chem. Int. Ed. 2011, 50, 276; e) Y. Furukawa, T. Ishiwata, K. Sugikawa, K. Kokado, K. Sada, Angew. Chem. Int. Ed. 2012, 51, 10566; f) Y. Wei, S. Han, D. A. Walker, P. E. Fuller, B. A. Grzybowski, Angew. Chem. Int. Ed. 2012, 51, 7435; g) S. Han, Y. Wei, B. A. Grzybowski, Chem. Eur. J. 2013, 19, 11194; h) D. Wu, J. J. Gassensmith, D. Gouvêa, S. Ushakov, J. F. Stoddart, A. Navrotsky, J. Am. Chem. Soc. 2013, 135, 6790.

[27] J. Mähler, I. Persson, Inorg. Chem. 2012, 51, 425.

[28] a) S. A. Dalrymple, M. Parvez, G. K. H. Shimizu, Chem. Commun. 2001, 2672; b) D. A. Beauchamp, S. J. Loeb, Chem. Eur. J. 2002, 8, 5084; c) D. S. Reddy, S. Duncan, G. K. H. Shimizu, Angew. Chem. Int. Ed. 2003, 42, 1360; d) V. Shivaiah, S. K. Das, Inorg. Chem. 2005, 44, 7313; e) A. M. Madalan, N. Avarvari, M. Andruh, New J. Chem. 2006, 30, 521; f) P. Thuéry, Inorg. Chem. 2010, 49, 9078.

[29] L. F. Kozin, V. T. Melekhin, Russ. J. Appl. Chem. 2004, 77, 1573. 